\title{
MEDIASI PENAL SEBAGAI ALTERNATIF PENYELESAIAN PERKARA KECELAKAAN LALU LINTAS DI POLRES PASURUAN
}

\author{
Eko Iskandar \\ eko.iskandar-2015@pasca.unair.ac.id \\ Program Studi Magister Kajian Ilmu Kepolisian \\ Sekolah Pascasarjana Universitas Airlangga \\ Jln. Airlangga No.4-6 Surabaya
}

\begin{abstract}
In Pasuruan Regional police station amount of accidents in 2018 has decreased, but amount of dead victims still relatively high. In 2018 there 533 events, in 2017 there 809 events and 2016 there 908 events, if on average there 756 events in the last 3 years. The majority of settlement the case uses the mediation of penal process. So the authors interested in researching the basis of the implementation of penal mediation as an alternative to the settlement of cases in traffic accidents in Pasuruan Regional Police and the obstacles the implementation of traffic accident settlement through mediation penalties. The method in this study uses a qualitative approach data collection techniques through interviews and documentation studies. Data analysis techniques based on data collection, data reduction, data display verification and confirmation of conclusions. The basis of implementation the mediation of law, among others, legal basis and sociological basis The juridical basis used includes the authority to "act according to self-assessment" as regulated in Article 18 of Law Number 2 of 2002. While the sociological basis includes the perpetrators and victims alike agreeing to make peace; In the event the offender is not entirely guilty; The impactor is willing to provide compensation of money and medical expenses to the victim; and the immature age of the traffic accident perpetrators. Barriers to the implementation the mediation of penalties include conflicts with penal system that applies in UULLAJ. The second obstacle the conflict between the interests of the perpetrators and victims, in this case between the wishes of the victims who sometimes expect high compensation or there are several parties from victims who do not agree with each other. The next obstacle is the existence of a clash in the value of legal certainty where compensation will basically not stop the accident case process.
\end{abstract}

Keywords: Penal Mediation, Traffic Accidents

\begin{abstract}
Di wilayah Polres Pasuruan angka kecelakaan sepanjang 2018 mengalami penurunan, namun jumlah korban meninggal masih terbilang tinggi. Tahun 2018 terjadi 533 kejadian, tahun 2017 terjadi 809 kejadian serta tahun 2016 terjadi 908 kejadian, jika dirata-rata terdapat 756 kejadian dalam kurun waktu 3 tahun terakhir. Mayoritas penyelesaian dari kasus tersebut menggunakan proses mediasi penal. Sehingga penulis tertarik meneliti mengenai dasar pelaksanaan mediasi penal sebagai alternatif penyelesaian perkara dalam tindak pidana kecelakaan lalu lintas di Polres Pasuruan serta hambatan pelaksanaan penyelesaian tindak pidana kecelakaan lalu lintas melalui mediasi penal. Metode yang digunakan dalam penelitian ini menggunakan pendekatan kualitatif dengan teknik pengumpulan data melalui wawancara dan studi dokumentasi. Teknik analisis data berdasarkan pengumpulan data, reduksi data, tampilan data serta verifikasi dan penegasan kesimpulan. Dasar dilaksanakannya mediasi penal antara lain dasar yuridis dan dasar sosiologis. Dasar yuridis yang digunakan antara lain Kewenangan untuk "bertindak menurut penilaian sendiri" sebagaimana diatur dalam Pasal 18 Undang-Undang Nomor 2 Tahun 2002. Sedangkan dasar sosiologis antara lain antara pelaku dan korban sama sama bersepakatan untuk melakukan perdamaian; Dalam kejadian tersebut pihak pelaku tidak sepenuhnya bersalah; Penabrak bersedia memberikan kompensasi sejumlah uang dan biaya pengobatan bagi korban; serta usia belum dewasa dari pelaku kecelakaan lalu lintas. Hambatan pelaksanaan mediasi penal antara lain adanya benturan dengan sistem pemidanaan yang berlaku dalam UULLAJ. Hambatan kedua adalah adanya benturan kepentingan pelaku dan korban yang dalam hal ini antara keingin korban yang terkadang mengharap kompensasi yang tinggi atau ada beberapa pihak dari korban yang tidak saling menyetujui. Hambatan berikutnya adalah adanya benturan pada nilai kepastian hukum yang mana ganti kerugian pada dasarnya tidak akan mengentikan proses kasus kecelakaan.
\end{abstract}

Kata Kunci : Mediasi Penal, Kecelakaan Lalu Lintas 


\section{A. Pendahuluan}

Perkembangan lingkungan strategis nasional dan internasional menuntut penyelenggaraan lalu lintas dan angkutan jalan yang sesuai dengan perkembangan ilmu pengetahuan dan teknologi, otonomi daerah, serta akuntabilitas penyelenggaraan negara. Oleh karena itu dalam penyelenggaraan berlalu-lintas ada 4 (empat) faktor utama yang harus diperhatikan, yaitu keamanan lalu lintas dan angkutan jalan adalah suatu keadaan terbebasnya setiap orang, barang, dan/atau kendaraan dari gangguan perbuatan melawan hukum, dan/atau rasa takut dalam berlalu-lintas; Keselamatan lalu lintas dan angkutan jalan adalah suatu keadaan terhindarnya setiap orang dari risiko kecelakaan selama berlalu-lintas yang disebabkan oleh manusia, kendaraan, jalan, dan/atau lingkungan; Ketertiban lalu lintas dan angkutan jalan adalah suatu keadaan berlalulintas yang berlangsung secara teratur sesuai dengan hak dan kewajiban setiap pengguna jalan; Kelancaran lalu lintas dan angkutan jalan adalah suatu keadaan berlalu-lintas dan penggunaan angkutan yang bebas dari hambatan dan kemacetan di jalan. ${ }^{1}$

Masalah lalu-lintas merupakan masalah yang dihadapi oleh negara-negara yang maju dan juga negara-negara berkembang seperti Indonesia. Namun di Indonesia, permasalahan yang sering dijumpai pada masa sekarang menjadi lebih parah dan lebih besar dari tahun tahun sebelumnya, baik mencakup kecelakaan, kemacetan dan polusi udara serta pelanggaran lalu lintas. ${ }^{2}$

Ruas jalan di wilayah Kabupaten Pasuruan masih jadi "momok" para pengguna jalan. Total panjang jalan di Kabupaten Pasuruan berdasarkan kondisi permukaan jalan di tahun 2017 dari 2.315,89 km, jalan dalam kondisi baik $50.1 \%$ atau 1.161,78 km dalam kondisi baik. Sedangkan $13.2 \%$ atau $306,34 \mathrm{~km}$ dalam kondisi rusak ringan dan $10,4 \%$ atau $241,30 \mathrm{~km}$ dalam kondisi rusak berat. Jadi kondisi jalan dalam keadaan rusak totalnya mencapai 23,6\% di tahun $2017 .^{3}$

Meski angka kecelakaan sepanjang 2018 ini mengalami penurunan, namun jumlah korban meninggal masih terbilang tinggi. Di tahun 2018 terjadi 533 kejadian, tahun 2017 terjadi 809 kejadian serta tahun 2016 terjadi 908 kejadian, yang jika dirata-rata maka terdapat 756 kejadian dalam kurun waktu 3 tahun terakhir. ${ }^{4}$

Kepolisian Republik Indonesia (Polri) merupakan alat negara yang berperan dalam pemeliharaan keamanan dan ketertiban masyarakat, penegakan hukum, perlindungan, pengayoman, dan pelayanan kepada masyarakat dalam rangka terpeliharanya keamanan dalam negeri. Penanganan kecelakaan lalu lintas, Polri selaku pihak yang bertanggung jawab menangani perkara ini akan melakukannya dengan cara yang profesional serta berupaya untuk mendamaikan para pihak 
yang mengalami kecelakaan melalui alternatif penyelesaian sengketa melalui cara mediasi penal, atau lebih dikenal dengan istilah mediasi pidana.

\footnotetext{
${ }^{1}$ Nurhasan, Juni 2017, Kebijakan Restorative Justice Dalam Penanganan Kasus Kecelakaan Lalu Lintas Di Wilayah Hukum Polres Wonosobo, Jurnal Hukum Khaira Ummah Vol. 12. No. hlm. 1

${ }^{2}$ Budiarto, Arif. dkk. 2007, Rekayasa Lalu Lintas, Solo : UNS Press, hlm.3.

${ }^{3}$ BPS Kabupaten Pasuruan, 2018, Kabupaten Pasuruan dalam Angka Tahun 2018 , hlm. 551

${ }^{4}$ Data Kecelakaan Lalu Lintas Polres Pasuruan Tahun 2018
} 
Mengenai mediasi penal sendiri merupakan salah satu bentuk alternatif penyelesaian sengketa di luar pengadilan. Pada umumnya penyelesaian di luar pengadilan digunakan di lingkungan kasus-kasus perdata tidak untuk kasus-kasus pidana. Berdasarkan perundang-undangan yang berlaku di Indonesia saat ini (hukum positif) pada prinsipnya kasus pidana tidak dapat diselesaikan di luar pengadilan, walaupun dalam hal-hal tertentu, dimungkinkan adanya penyelesaian kasus pidana di luar pengadilan (mediasi penal $)^{5}$

Mediasi penal (penal mediation) sering juga disebut dengan berbagai istilah, antara Iain : "mediation in criminal cases" atau "mediation in penal matters" yang dalam istilah Belanda disebut strafbemiddeling, dalam istilah Jerman disebut "Der Aubergerichtliche Tatausgleich" (disingkat dan dalam istilah Perancis disebut "de mediation ponale"). Karena mediasi penal terutama mempertemukan antara pelaku tindak pidana dengan korban, maks mediasi penal ini sering juga dikenal dengan istilah "Victim- Offender Mediation" (VOM), Tater-Opfer-Ausgleich (TOA), atau Offender-victim Arrangement (OVA) ${ }^{6}$

Aturan internal Polri sendiri, penyelesaian perkara pidana melalui mekanisme mediasi penal ini telah dikenal sejak keluarnya Surat Kapolri No Pol: B/3022/XII/2009/SDEOPS tanggal 14 Desember 2009 tentang Penanganan Kasus Melalui Alternative Dispute Resolution (ADR) meskipun sifatnya hanya sebagian saja. Dalam Surat Kapolri ini menekankan bahwa penyelesaian kasus pidana dengan menggunakan ADR, baru dapat dilaksanakan apabila ada kesepakatan dari para pihak baik korban maupun tersangka atau pihak yang bersengketa namun apabila tidak terdapat kesepakatan maka tetap diselesaikan sesuai dengan prosedur hukum yang berlaku.

Pintu masuk pemberlakukan mediasi penal adalah melalui diskresi sebagai kewenangan Polri. Dasar hukum diskresi bagi aparat Kepolisian Negara Republik Indonesia (Polri) dalam melaksanakan tugasnya dapat dilihat pada Undang-undang Nomor 02 Tahun 2002 tentang Kepolisian Negara Republik Indonesia di dalam Pasal 15 ayat (2) huruf k, disebutkan bahwa Kepolisian Negara Republik Indonesia sesuai dengan peraturan perundang-undangan lainnya berwenang melaksanakan kewenangan lain yang termasuk dalam lingkup tugas kepolisian.

Yang menjadi permasalahan adalah selama ini Mediasi penal dijalankan tanpa adanya ukuran yang jelas. Berapa besar ukuran ganti rugi, kompetensi penyidik dalam menangani masalah mediasi penal, sampai pada legalitas atau keabsahan pelaksanaan mediasi penal tersebut. Permasalahan mediasi penal yang mempertanyakan aspek legalitas tersebut sebagaimana penelitian dari Akbar Hairudin dengan jurnal berjudul Legalitas Penyidik Polri Pada Penyelesaian Perkara Kecelakaan Lalu Lintas. ${ }^{7}$ 
5 Arief, Barda Nawawi, 2012, Mediasi Penal (Penyelesaian Perkara di Luar Pengadilan), Semarang: Pustaka Magister, hlm. 2

${ }^{6}$ Ibid.

${ }^{7}$ Hairudin, Akbar, Juni 2016, Legalitas Penyidik Polri Pada Penyelesaian Perkara Kecelakaan Lalu Lintas, Lex et Societatis, Vol. IV/No. 6

Selain permasalahan diatas, penyelesaian sengketa secara litigasi berdasarkan penelitian dari Akmal adalah tidak efektif karena selain menambah penumpukan perkara, dalam operasionalnya upaya litigasi dinilai lamban, mahal, memboroskan energi, waktu dan uang. Sehingga dengan ketiadaan jalur litigasi yang tidak memberikan win-win solution, maka dibutuhkan upaya lain di luar litigasi sebagai alternatif penyelesaian masalahnya yakni melalui mediasi penal yang diinisiasi oleh anggota Polri melalui kewenangan diskresi yang dimilikinya saat penyelidikan maupun penyidikan. ${ }^{8}$

Eksistensi penyelesaian perkara di luar pengadilan melalui restoratif justice atau mediasi penal, merupakan dimensi baru dikaji dari aspek teoritis dan praktik. Dikaji dari dimensi praktik maka mediasi penal akan berkorelasi dengan pencapaian dunia peradilan. Seiring berjalannya waktu dimana semakin hari terjadi peningkatan jumlah volume perkara dengan segala bentuk maupun variasinya yang masuk ke pengadilan, sehingga konsekuensinya menjadi beban bagi pengadilan dalam memeriksa dan memutus perkara sesuai asas "peradilan sederhana, cepat dan biaya ringan" tanpa harus mengorbankan pencapaian tujuan peradilan yaitu kepastian hukum, kemanfaatan dan keadilan. Apakah semua macam perkara pidana harus diajukan dan diselesaikan dimuka pengadilan, ataukah ada perkara- perkara tertentu, yang memungkinkan untuk diselesaikan melalui pola mediasi penal. Pada polarisasi dan mekanisme mediasi penal, sepanjang hal tersebut sungguhsungguh dikehendaki bersama oleh para pihak (tersangka dan korban), serta untuk mencapai kepentingan yang lebih luas, yaitu terpeliharanya harmonisasi sosial.

Sehingga berdasarkan latar belakang tersebut penulis tertarik untuk mengangkat tema tentang Mediasi Penal Sebagai Alternatif Penyelesaian Perkara Kecelakaan Lalu Lintas di Polres Pasuruan

\section{B. Metode}

Penelitian ini menggunakan pendekatan kualitatif, karena permasalahan berhubungan dengan manusia yang secara fundamental bergantung pada pengamatan. Hal ini diperkuat dengan apa yang disampaikan oleh John W.Creswell, bahwa penelitian kualitatif merupakan metode-metode untuk mengeksplorasi dan memahami makna yang oleh sejumlah individu atau sekelompok orang dianggap berasal dari masalah sosial atau kemanusiaan. ${ }^{9}$ Pendekatan kualitatif ini merupakan pendekatan yang dilakukan secara utuh kepada subjek penelitian dimana terdapat sebuah peristiwa yakni permasalahan kecelakaan lalu lintas yang mana dalam praktiknya adalah 
seharusnya lebih efisien jika dilakukan penyelesaian di luar pengadilan waluaupun mekanisme tersebut tidak ada dalam SOP nya

${ }^{8}$ Akmal, 2013, Mediasi Penal Sebagai Alternatif Penyelesaian Perkara Pada Tindak Pidana Kecelakaan Lalu Lintas Yang Mengalami Kerugian Material (Studi Di Polres Jember), Jurnal. Malang :Unibraw, hlm. 6

hlm. 4

${ }^{9}$ Creswell, John W. 2016, Research Design (edisi 4), Yogyakarta : Pustaka Pelajar, 
untuk saat ini. Hal ini tentunya untuk mengurangi penumpukan kasus serta pembengkakan biaya operasional.

Dalam penelitian kualitatif ini digunakan metode deskriptif analitis yang menurut Sugiono metode deskriptif adalah suatu metode yang berfungsi untuk mendeskripsikan atau memberi gambaran terhadap obyek yang diteliti melalui data atau sampel yang telah terkumpul sebagaimana adanya tanpa melakukan analisis dan membuat kesimpulan yang berlaku untuk umum". ${ }^{10}$ Dengan kata lain penelitian deskriptif analitis mengambil masalah atau memusatkan perhatian kepada masalah-masalah sebagaimana adanya saat penelitian dilaksanakan hasil penelitian yang kemudian diolah dan dianalisis untuk diambil kesimpulannya. Dikatakan deskriptif karena bertujuan memperoleh pemaparan yang obyektif mengenai analisis dalam membahas permasalahan yang diangkat.

Berdasarkan pendapat tersebut, maka penelitian kualitatif dengan metode deskriptif analisis sangat tepat untuk digunakan dalam penelitian yang penulis lakukan yakni mengenai masalah kecelakaan lalu lintas karena penelitian ini sangat memungkinkan untuk meneliti fokus permasalahan yang akan penulis teliti secara mendalam terutama mengenai bagaimana nantinya paparan detail mengenai bagaimanakah pelaksanaan mediasi penal sebagai alternatif penyelesaian perkara dalam tindak pidana kecelakaan lalu lintas di Polres Pasuruan serta mengenai bagaimanakah dampak bagi korban, pelaku, dan kepolisian dari proses penyelesaian tindak pidana kecelakaan lalu lintas melalui mediasi penal.

\section{Pembahasan}

\section{Dasar Pelaksanaan Mediai Penal Sebagai Alternatif Penyelesaian Perkara Dalam Tindak Pidana Kecelakaan Lalu Lintas Di Polres Pasuruan}

\section{Faktor Penyebab Kecelakaan}

Jika diuraikan lebih lanjut mengenai penyebab kecelakaan yang terjadi di wilayah hukum Polres Pasuruan, maka akan didapatkan beberapa faktor penyebabnya. Dari penelitian terdahulu didapatkan data bahwa kecelakaan lalu lintas dapat terjadi karena beberapa faktor yang saling berinteraksi yaitu faktor pengemudi (manusia), lalu lintas, jalan, kendaraan dan lingkungan. Sedangkan penelitian yang telah dilakukan oleh Suraji di tahun 2005 pada jaringan lalu lintas di kawasan kota Malang didapatkan bahwa kecelakaan sepeda motor dipengaruhi oleh berbagai faktor antara lain kondisi jalan, kondisi kendaraan, faktor manusia (pengendara), dan

\footnotetext{
${ }^{10}$ Sugiono, 2011, Metode Penelitian Kuantitatif Kualitatif dan R\&D, Bandung: Alfabeta, hlm. 29
} 
lingkungan. Dalam hal ini faktor manusia memiliki kontribusi terbesar pada kecelakaan sepeda motor. Menurut Direktorat Jenderal Perhubungan Darat, besarnya persentase masing-masing faktor penyebab kecelakaan lalu lintas di Indonesia yaitu faktor manusia sebesar 93,52\%, faktor kendaraan sebesar 2,76\%, faktor jalan 3,23\%, dan faktor lingkungan sebesar $0,49 \% .{ }^{11}$ Hal tersebut sebagaimana di Polres Pasuruan yang mana $81 \%$ kejadian kecelakaan karena faktor manusia, $17 \%$ faktor jalan dan $2 \%$ dikarenakan faktor lingkungan. Mengenai hal ini dipaparkan secara lebih lengkap sebagai berikut:

a. Faktor manusia

Dari data di Polres Pasuruan diketahui ada beberapa faktor dominan penyebab kecelakaan lalu lintas dari faktor manusia atau pengemudi kendaraan bermotor yang antara lain dikarenakan oleh kondisi :

lengah, mengantuk, mabuk, lelah, tidak terampil, tidak tertib dan dalam kecepatan tinggi.

b. Faktor kendaraan

Faktor kendaraan merupakan faktor yang juga berkontribusi dalam menimbulkan kecelakaan lalu lintas, faktor penyebab kecelakaan yang berasal dari faktor kendaraan antara lain : kondisi rem yang kurang baik, ban pecah, selip, serta tidak ada atau tidak menyalanya lampu kendaraan terutama ketika mengemudi pada malam hari.

c. Faktor lingkungan

Faktor ini juga mengambil porsi yang menjadi sebab terjadinya kecelakaan. Walupun tidak sebanyak faktor lain tetapi beberapa kasus kecelakaan lalu lintas terjadi diakibatkan faktor lingkungan yaitu : jalan lubang, jalan rusak, jalan licin, jalan menikung, lampu jalan tidak ada dan kondisi hujan.

\section{Dasar Pelaksanaan Mediasi Panel}

Peranan polisi dalam penegakan hukum dapat ditemukan di dalam perundang undangan yang mengatur tentang hak dan kewajiban polisi yaitu Undang-Undang No. 2 tahun 2002 Tentang Kepolisian Negara Republik Indonesia. Dalam Undang-Undang tersebut memberikan kewenangan kepada polisi untuk menyelesaikan perkara kecelakaan lalu lintas termasuk dengan kewenangan melakukan mediasi. Tugas-tugas polisi preventif bersifat mencegah, mengatur atau melakukan tindakan- tindakan yang berupa usaha, kegiatan demi terciptanya keamanan, ketertiban, kedamaian dan ketenangan di dalam masyarakat. Usaha- usaha yang dilakukan polisi itu berupa kegiatan patroli, penyuluhan, pantauan dan pertolongan pada masyarakat dimana bila dikaitkan dengan Undang-Undang disebut dengan 
${ }^{11}$ Marsaid, Nopember 2013, Faktor Yang Berhubungan Dengan Kejadian Kecelakaan Lalu Lintas Pada Pengendara Sepeda Motor Di Wilayah Polres Kabupaten Malang, Jurnal Ilmu Keperawatan - Volume 1, No. 2, hal. 102 
pengayom, pelindung dan pelayan masyarakat. Tugas-tugas preventif ini lebih berorientasi pada kesejahteraan masyarakat umum.

Tugas penyidikan yang dilakukan oleh penyidik Polri adalah merupakan penyidik tunggal bagi tindak pidana umum. Tugasnya sebagai penyidik sangat sulit dan membutuhkan tanggung jawab yang sangat besar, karena penyidikan merupakan tahap awal dari rangkaian proses penyelesaian perkara pidana yang nantinya akan sangat berpengaruh bagi tahap proses peradilan selanjutnya.

Penyidikan merupakan aktifitas yuridis yang dilakukan oleh aparat penyidik untuk mencari dan menemukan kebenaran sejati serta membuat terang, jelas tentang peristiwa tindak pidana yang terjadi. Dengan demikian tujuan utama dari penyidikan adalah untuk mencari serta mengumpulkan bukti, yang dengan bukti- bukti itu dapat membuat terang suatu tindak pidana yang terjadi dan guna menemukan tersangkanya. Penyelesaian perkara pidana merupakan tugas dan tanggung jawab penyidik, penuntut umum dan hakim. Dengan singkat penyelesaian perkara pidana dapat meliputi

a. Penyelidikan dan penyidikan oleh Kepolisian Negara;

b. Penuntutan dan pelaksanaan putusan hakim oleh Kejaksaan Negeri;

c. Peradilan perkara oleh Hakim.

Sedangkan tugas polisi represif lebih berorientasi pada penegakanhukum pidana yang bersifat menindak terhadap para pelanggar hukum untuk selanjutnya diproses dalam sistem peradilan pidana sesuai dengan ketentuan- ketentuan yang berlaku baik itu di dalam KUHAP maupun peraturan perundang- undangan lainnya.

Pada undang-undang Nomor 22 Tahun 2009, perkara kecelakaan lalu lintas terbagi atas 3 jenis, yaitu :

1) Kecelakaan Lalu Lintas ringan, yaitu kecelakaan yang mengakibatkan kerusakan kendaraan dan/atau barang.

2) Kecelakaan Lalu Lintas sedang, yaitu kecelakaan yang mengakibatkan luka ringan dan kerusakan kendaraan dan/atau barang.

3) Kecelakaan Lalu Lintas berat, yaitu kecelakaan yang mengakibatkan korban meninggal dunia atau luka berat.

Ketiga jenis kecelakaan tersebut di atas, semuanya dilaksanakan melalui mekanisme acara pemeriksaan singkat atau acara pemeriksaan biasa karena melihat tidak adanya ancaman hukuman yang sama dan bisa diselesaikan melalui acara pemeriksaan cepat (Tipiring).

Alur proses peradilan bagi pelanggaran yang melalui acara pemeriksaan cepat, Polisi selaku penyidik / penyidik pembantu memberikan surat Tilang kepada pelanggar yang memuat data 
pelanggar, identitas kendaraan pelanggar, pasal pelanggaran, tempat dan tanggal sidang, barang sitaan, tanda tangan kesiapan hadir sidang atau diwakilkan, dan sebagainya yang termuat dalam lembaran tilang tersebut, selanjutnya petugas polisi yang ditelah ditunjuk menjadwalkan pelaksaan sidang melalui panitera pengadilan. Setelah Vonis Hakim dijatuhkan maka pelanggar dapat membayar denda pelanggaran kepada panitera pengadilan dan barang sitaan dapat diserahkan kembali kepada pelanggar.

Pelaksanaan penyelidikan dan penyidikan pada perkara kecelakaan lalu lintas tidak jauh berbeda dengan pelaksanaan penyelidikan dan penyidikan pidana lainnya, oleh karena perkara kecelakaan lalu lintas juga merupakan perkara pidana yang berprinsip formil pada Kitab UndangUndang Hukum Acara Pidana (KUHAP). Adanya tindakan penyelidikan yang dilakukan oleh pihak Kepolisian berupa : a) menerima informasi tentang kecelakaan baik secara langsung oleh pihak yang terlibat dalam kecelakaan tersebut atau ditemukan oleh pihak petugas Kepolisian saat melaksanakan tindakan patroli kepolisian, b) mendatangi TKP (Tempat Kejadian Perkara) untuk melaksanakan penanganan TKP dan pengolahan TKP sebagai bahan pertimbangan langkah elanjutnya, c) mengecek adanya korban manusia (luka / meninggal dunia), membawa ke rumah sakit terdekat dan membuat visum et repertum (VER), d) membawa dan menyita barang bukti yang ditemukan di TKP, e) membuat berita acara pemeriksaan barang bukti dan TKP, f) mencari dan menemukan saksi di sekitar TKP, g) tindakan lainnya yang diperlukan untuk membuktikan adanya tindak pidana kecelakaan lalu lintas. Alur proses peradilan yang menggunakan mekanisme acara pemeriksaan biasa dan singkat haruslah menempatkan Jaksa sebagai penuntut umum sebelum perkara tersebut disidangkan dan dijatuhkan vonis oleh Hakim.

Surat Pemberitahuan Dimulainya Penyidikan (SPDP) yang diserahkan oleh pihak penyidik kepada pihak Kejaksaan adalah proses awal koordinasi antara pihak Kejaksaan sebagai penuntut Umum dan pihak Kepolisian sebagai Penyidik. Setelah berkas perkara tersebut lengkap yang dinyatakan oleh formulir P21 dari pihak Kejaksaan, Penyidik untuk selanjutnya menyerahkan tanggung jawab tersangka dan barang bukti kepada pihak Kejaksaan untuk selanjutnya menunggu jadwal sidang dan proses peradilan sampai penjatuhan hukuman (Vonis) oleh Hakim.

Prosedur penanganan diatas merupakan prosedur kebijakan penal yang mengutamakan vonis pemidanaan dalam konsepnya. Tetapi dalam ranah hukum ada kebijakan kriminal dengan prinsip prevention without punishment/ tanpa menggunakan sistem peradilan pidana. ${ }^{12}$

Munculnya ide restorative justice melalui mediasi penal diakibatkan atas dasar sistem peradilan pidana dengan pemenjaraan yang dianggap tidak efektif menyelesaikan konflik sosial. Faktanya, pihak yang terlibat dalam konflik tersebut tidak dilibatkan dalam penyelesaian konflik. Korban tetap saja menjadi korban, pelaku yang dipenjara juga memunculkan persoalan baru bagi keluarganya dan lain-lain. Bukan berarti pidana penjara ditiadakan 
12 Muladi, 2016, Kompleksitas Perkembangan Tindak Pidana dan Kebijakan Kriminal. Cet. Pertama, Bandung: P.T.Alumni, hal. 161 
sebagai akibat adannya konsep restorative justice, dalam perkara-perkara tertentu yang berkaitan dengan berharga nyawa seseorang, maka pidana penjara masih dapat dipergunakan. Meskipun akan dinyatakan secara berbeda dalam budaya yang berbeda, pendekatan restorative justice ini sangat umum bagi sebagian besar masyarakat tradisional. ${ }^{13}$ Keunggulan utama suatu penyelesaian perkara dengan prinsip restorative justice melalui mediasi non penal (di luar pengadilan) adalah keputusan yang dibangun oleh para pihak sendiri dengan solusi sama-sama menang (wi-win solution) yang lebih mencerminkan rasa keadilan termasuk pula dalam kasus-kasus kecelakaan lalu lintas.

Diskresi berasal dari kata-kata bahasa Inggris yang artinya kebijaksanaan, keleluasaan atau kemampuan untuk memilih rencana kebijaksanaan atau mempertimbangkan bagi diri sendiri. ${ }^{14}$ Istilah diskresi Kepolisian dapat diartikan suatu kebijaksanaan berdasarkan keluasannya untuk melakukan suatu tindakan atas dasar pertimbangan dan keyakinan dirinya. Jadi diskresi itu dilakukan bukan lepas dari ketentuan hukum tetapi diskresi itu tetap dilakukan dalam kerangka hukum. ${ }^{15}$

Pelaksanaan diskresi pada Satuan Lalu Lintas Polres Pasuruan berbeda-beda porsinya, karena bersifat subyektif dan situasional. Dalam hal ini pelaksanaan diskresi tersebut tergantung oleh kondisi serta situasi setiap masalah yang dihadapi setiap anggota yang ada di lapangan. Menurut Kanit Laka Lantas Polres Pasuruan : "Bahwa Pertimbangan Polisi dalam melakukan diskresi dalam perkara lalu lintas yaitu pelaksanaan diskresi bersifat subyektif dan tergantung pada kasusnya, dapat mempersingkat waktu, dan kesepakatan bersama kedua belah pihak". ${ }^{16}$

Sekalipun diskresi penyidik bersifat subyektif dan situasional, namun diskresi juga ada dasar hukumnya, sehingga tidak sembarangan. Dasar hukum tersebut dapat ditemukan dalam undang-undang kepolisian, yaitu Undang-Undang Nomor 2 Tahun 2002 tentang Kepolisian, khususnya pada Pasal 18 Ayat (1). Dalam hal ini seorang aparat penyidik dituntut harus penuh tanggung jawab dapat bertindak menurut penilaiannya sendiri sesuai wewenangnya menurut kepentingan umum.

Untuk menjalankan proses Mediasi Penal pada perkara kecelakaan Lalu Lintas baik ringan, sedang maupun berat ditetapkan syarat sebagaimana disebutkan dalam Surat Edaran Kapolri No. SE / 8/VII/2018 tentang Penerapan Keadilan Restoratif (Restorative Justice) yakni: a. Terpenuhi syarat materiil yaitu:

\footnotetext{
13 Howard Zehr \& Ali Gohar, 2003, The Little Book of Restorative Justice, Pennsylvania : Good Books, hal. 23

${ }^{14}$ Utomo, Warsito Hadi. 2005, Hukum Kepolisian Di Indonesia. Prestasi Pustaka, Jakarta, hal. 105

${ }^{15}$ Utomo, Op.Cit., hal. 106

${ }^{16}$ Wawancara dengan Aiptu Triyono Anggota Unit Laka Lantas Polres Pasuruan tanggal 3 April 2019.
} 
1) Tidak menimbulkan keresahan masyarakat dan tidak ada penolakan masyarakat;

2) Tidak berdampak konflik sosial;

3) Adanya pernyataan dari semua pihak yang terlibat untuk tidak keberatan, dan melepaskan hak menuntutnya di hadapan hukum;

4) Prinsip pembatas:

a) Pada pelaku:

(1) Tingkat kesalahan pelaku relatif tidak berat, yakni kesalahan (mens rea dalam bentuk kesengajaan (dolus) terutama kesengajaan sebagai maksud atau tujuan (opzet als oogmerk);

(2) Pelaku bukan residivis;

b) Pada tindak pidana dalam proses:

(1) Penyelidikan;

(2) Penyidikan sebelum SPDP (Surat Perintah Dimulainya

Penyidikan) dikirim ke Penuntut Umum ;

b. Terpenuhi syarat formil yaitu:

1) Surat permohonan perdamaian kedua belah pihak (pelapor dan terlapor);

2) Surat pernyataan perdamaian (akte dading) dan penyelesaian perselisihan para pihak yang berperkara (pelapor, dan/atau keluarga pelapor, terlapor dan/atau keluarga terlapor dan perwakilan dari tokoh masyarakat) diketahui oleh atasan penyidik;

3) Berita Acara Pemeriksaan Tambahan pihak yang berperkara setelah dilakukan penyelesaian perkara melalui keadilan restorative (Restorative Justice);

4) Rekomendasi gelar perkara khusus yang menyetujui penyelesaian keadilan restoratif (restorative justice);

5) Pelaku tidak keberatan atas tanggung jawab, ganti rugi, atau dilakukan dengan sukarela;

6) Semua tindak pidana dapat dilakukan restorative justice terhadap kejahatan umum yang tidak menimbulkan korban manusia;

Dasar-dasar yuridis tersebutlah yang digunakan oleh aparat Kepolisian Resort Pasuruan untuk melaksanakan mediasi penal/ ADR yang kemudian diperkuat dengan adanya surat kesepakatan perdamaian oleh kedua belak pihak untuk tidak saling menuntut di kemudian hari. Hal ini sebagaimana disebutkan dalam Pasal 236 UULLAJ yang berbunyi :

(1) Pihak yang menyebabkan terjadinya Kecelakaan LaluLintas sebagaimana dimaksud dalam Pasal 229 wajibmengganti kerugian yang besarannya ditentukan berdasarkan putusan pengadilan. 
(2) Kewajiban mengganti kerugian sebagaimana dimaksudpada ayat (1) pada Kecelakaan Lalu Lintas sebagaimanadimaksud dalam Pasal 229 ayat (2) dapat dilakukan diluar pengadilan jika terjadi kesepakatan damai di antarapara pihak yang terlibat.

Secara faktual di Polres Pasuruan, berdasarkan data disebutkan bahwa pada tahun 2017 dari total kejadian kecelakaan lalu lintas ada 566 kasus yang diselesaikan melalui mediasi penal atau dalam hal ini disebut Alternative Dispute Resolution, sebagaimana tabel berikut :

Tabel 3

Rekapitulasi Penanganan Kecelakaan Lalu Lintas Tahun 2017

\begin{tabular}{|c|c|c|c|c|c|c|c|c|c|c|}
\hline \multirow{2}{*}{ NO } & \multirow{2}{*}{ KESATUAN } & \multirow{2}{*}{$\begin{array}{c}\text { JUMLAH } \\
\text { LAKA } \\
\end{array}$} & \multicolumn{5}{|c|}{ BENTUK PENYELESAIAN } & \multirow{2}{*}{$\begin{array}{c}\text { JMLH } \\
\text { SELRA }\end{array}$} & \multirow{2}{*}{ PROSES } & \multirow{2}{*}{ KET } \\
\hline & & & P21 & SP3 & ADR & BAS & LAIN-LAIN & & & \\
\hline 1 & JANUARI & 67 & 2 & 6 & 42 & & & 50 & 17 & 67 \\
\hline 2 & PEBRUARI & 52 & 2 & 2 & 39 & & & 43 & 9 & 52 \\
\hline 3 & MARET & 59 & 2 & 1 & 43 & & & 46 & 13 & 59 \\
\hline 4 & APRIL & 85 & 3 & & 68 & & & 71 & 14 & 85 \\
\hline 5 & MEI & 89 & 2 & 4 & 70 & & & 76 & 13 & 89 \\
\hline 6 & JUNI & 83 & 2 & & 68 & & & 70 & 13 & 83 \\
\hline 7 & JULI & 72 & 2 & 4 & 59 & & & 65 & 7 & 72 \\
\hline 8 & AGUSTUS & 53 & 5 & 2 & 41 & & & 48 & 5 & 53 \\
\hline 9 & SEPTEMBER & 79 & 2 & 5 & 55 & & & 62 & 17 & 79 \\
\hline 10 & OKTOBER & 65 & 4 & 6 & 44 & & & 54 & 11 & 65 \\
\hline 11 & NOVEMBER & 49 & 5 & 6 & 25 & & & 36 & 13 & 49 \\
\hline \multirow[t]{2}{*}{12} & DESEMBER & 56 & 3 & 3 & 12 & & & 18 & 38 & 56 \\
\hline & TOTAL & 809 & 34 & 39 & 566 & & & 639 & 170 & 809 \\
\hline
\end{tabular}

Sumber : Data Sekunder Polres Pasuruan Tahun 2017

Pada tabel penyelesaian perkara (Selra) diatas diketahui pula 88,5\% kejadian laka lantas diselesaikan melalui proses mediasi penal. Sedangkan pada tahun 2018, sampai dengan bulan Agustus 2018 terdapat 553 kejadian kecelakaan lalu lintas dengan 245 kasus diselesaikan melalui mediasi penal atau sebanyak $68,2 \%$ yang sebagaimana ditunjukkan dalam data berikut :

\section{Tabel 4}

Rekapitulasi Penanganan Kecelakaan Lalu Lintas Tahun 2018 (Sampai Dengan Bulan Agustus)

\begin{tabular}{|c|c|c|c|c|c|c|c|c|c|c|}
\hline \multirow{2}{*}{ NO } & \multirow{2}{*}{ KESATUAN } & \multirow{2}{*}{$\begin{array}{c}\text { JUMLAH } \\
\text { LAKA }\end{array}$} & \multicolumn{5}{|c|}{ BENTUK PENYELESAIAN } & \multirow{2}{*}{$\begin{array}{c}\text { JMLH } \\
\text { SELRA }\end{array}$} & \multirow{2}{*}{ PROSES } & \multirow{2}{*}{ KET } \\
\hline & & & P21 & SP3 & ADR & BAS & LAIN-LAIN & & & \\
\hline 1 & JANUARI & 83 & 3 & 8 & 59 & & & 70 & 13 & 83 \\
\hline 2 & PEBRUARI & 59 & 3 & 5 & 35 & & & 43 & 16 & 59 \\
\hline 3 & MARET & 58 & 3 & 7 & 25 & & 1 & 48 & 10 & 58 \\
\hline 4 & APRIL & 72 & 3 & 5 & 15 & & & 57 & 15 & 72 \\
\hline 5 & MEI & 80 & 2 & 7 & 45 & & & 54 & 26 & 80 \\
\hline 6 & JUNI & 54 & 2 & 7 & 25 & & & 34 & 20 & 54 \\
\hline 7 & JULI & 72 & 1 & 4 & 23 & & & 28 & 44 & 72 \\
\hline 8 & AGUSTUS & 75 & 3 & 4 & 18 & & & 25 & 50 & 75 \\
\hline 9 & SEPTEMBER & & & & & & & & & \\
\hline 10 & OKTOBER & & & & & & & & & \\
\hline 11 & NOVEMBER & & & & & & & & & \\
\hline 12 & DESEMBER & & & & & & & & & \\
\hline & TOTAL & 553 & 20 & 47 & 245 & & 1 & 359 & 194 & 553 \\
\hline
\end{tabular}


Sumber : Data Sekunder Polres Pasuruan Tahun 2018

Mediasi penal memang berprinsip keseimbangan keadilan bagi pelaku tindak pidana serta korbannya sendiri, dengan mengutamakan pembinaan daripada pembalasan sehingga jika sudah tercapai keseimbangan keadilan ini perkara dianggap selesai dan perkara dihentikan dengan SP3.

Terjadinya peristiwa kecelakaan lalu lintas yang menyebabkan kerugian secara materi pada umumnya tidak ada unsur kesengajaan dan yang ada unsur kealpaan. Antara pelaku dan pihak keluarga korban biasanya

saling menyadari sehingga dalam menyelesaikan perkara mereka memilih diluar pengadilan atau dengan cara damai. Jadi bentuk penyelesaian perkara lalu lintas di luar pengadilan dengan cara damai maksudnya antara pelaku dan pihak keluarga korban sepakat setelah mengadakan musyawarah untuk menyelesaikan perkara secara kekeluargaan. Perdamaian yang terjadi antara pelaku dengan korban tersebut disertai dengan pemberian ganti rugi dalam bentuk materi sebagai bentuk pertanggungjawaban secara perdata pelaku kepada korban kecelakaan lalu lintas. Akan tetapi untuk besaran ganti kerugian yang diberikan kepada pelaku kepada korban disesuaikan dengan kesepakatan antara kedua belah pihak dengan melihat kemampuan dari pelaku untuk memberikan ganti rugi.

\section{Kesimpulan}

1. Dasar dilaksanakannya mediasi penal antara lain dasar yuridis dan dasar sosiologis. Dasar yuridis yang digunakan antara lain Kewenangan untuk "bertindak menurut penilaian sendiri” sebagaimana diatur dalam Pasal 18 Undang-Undang Nomor 2 Tahun 2002 Tentang Kepolisian Negara Republik Indonesia yang dikuatkan dengan Surat Kapolri Nopol B/3022/ XII/2009/Sdeops tanggal 14 Desember 2009 tentang penanganan kasus melalui Alternative Dispute Resolution (ADR) yang dipertegas dengan Surat Edaran Kapolri No. SE / 8/VII/2018 tentang Penerapan Keadilan Restoratif (Restorative Justice) dan Surat Telegram Kapolda Jatim Nomor ST/476/II/2010/Ditlantas yang memerintahkan agar para penyidik di wilayah Jawa Timur yang menangani kasus kecelakaan lalu lintas yang mengakibatkan luka ringan / kerugian materiil dapat diselesaikan melalui konsep Alternative Dispute Resolution. Sedangkan dasar sosiologis antara lain antara pelaku dan korban sama sama bersepakatan untuk melakukan perdamaian; Dalam kejadian tersebut pihak pelaku tidak sepenuhnya bersalah yang mana berdasarkan gelar perkara diketahui bahwa pihak korban juga lalai dalam mengemudikan kendaraannya sehingga terjadi kecelakaan; Penabrak bersedia memberikan kompensasi sejumlah uang dan biaya pengobatan bagi korban; serta usia belum dewasa dari pelaku kecelakaan lalu lintas. 
2. Hambatan pelaksanaan mediasi penal antara lain dikarenakan adanya benturan dengan sistem pemidanaan yang berlaku sebagaimana dalam UULLAJ Pasal 230 yang merujuk pada proses acara berdasarkan ketentuan peraturan perundangan yang berlaku yang dalam hal ini tercantum secara formal pada KUHAP oleh sebab itu segala bentuk penyelesaian di luar KUHAP akan kontradiktif dengan Undang- undang Lalu Lintas dan Angkutan Jalan sebagai hukum materiil. Selain itu surat pernyataan kesepakatan perdamaian yang ditandatangani kedua belah pada dasarnya bukanlah alasan penghapus pidana. Hambatan kedua adalah adanya benturan kepentingan pelaku dan korban yang dalam hal ini antara keingin korban yang terkadang mengharap kompensasi yang tinggi atau ada beberapa pihak yang dari korban yang tidak saling menyetujui kompensasi yang disepakati sedangkan si pelaku juga bukan orang yang mampu secara finansial, maka hal ini akan membuat hambatan dalam mediasi penal. Hambatan berikutnya adalah adanya benturan pada nilai kepastian hukum yang mana ganti kerugian pada dasarnya tidak akan mengentikan proses kasus kecelakaan. Sehingga kekhawatiran akan penerusan kasus ke meja persidangan akan terus membayangi, padahal telah terjadi kesepakatan para pihak akan perdamaian dan kompensasi yang diberikan. Proses beracara dalam mediasi penal yang tertuang dalam Surat Kapolri dan Surat Edaran tidak termasuk dalam peraturan perundang-undangan (regeling) dan hanya sebagai peraturan kebijakan (beleidsregel) saja yang menjadikan landasan hukum dari proses beracara dalam mediasi penal tidaklah kuat secara formil dan rentan menimbulkan ketidakpastian hukum karena akan secara pasti aturan tersebut bisa dikesampingkan dengan proses beracara dari KUHAP. Walaupun ada beberapa hambatan tersebut akan tetapi proses mediasi penal saat ini dan untuk prospek penegakan hukum kedepannya sangat dibutuhkan untuk efisiensi waktu serta penyeimbangan hak antara pelaku dan korban sehingga tidak ada yang dirugikan pada masing-masing pihak. Tetapi untuk memaksimalkan hal ini mediasi penal membutuhkan suatu bentuk jaminan kepastian hukum yang mengatur secara formil dalam aturan perundangan sebagai jenis-jenis aturan perundangan yang sesuai dengan UU No. 12 Tahun 2011.

\section{Bibliography}

Buku

Akmal, 2013, Mediasi Penal Sebagai Alternatif Penyelesaian Perkara

Pada Tindak Pidana Kecelakaan Lalu Lintas Yang Mengalami

Kerugian Material (Studi Di Polres Jember), Jurnal. Malang

:Unibraw. 
Arief, Barda Nawawi, 2012, Mediasi Penal (Penyelesaian Perkara di Luar Pengadilan), Semarang: Pustaka Magister.

Arif, Budiarto. dkk. 2007, Rekayasa Lalu Lintas, Solo : UNS Press. BPS Kabupaten Pasuruan, 2018, Kabupaten Pasuruan dalam Angka Tahun 2018

Creswell, John W. 2016, Research Design (edisi 4), Yogyakarta : Pustaka Pelajar.

Data Kecelakaan Lalu Lintas Polres Pasuruan Tahun 2018

Hairudin, Akbar, Juni 2016, Legalitas Penyidik Polri Pada Penyelesaian Perkara Kecelakaan Lalu Lintas, Lex et Societatis, Vol. IV/No. 6

Howard Zehr \& Ali Gohar, 2003, The Little Book of Restorative Justice, Pennsylvania : Good Books.

Marsaid, Nopember 2013, Faktor Yang Berhubungan Dengan Kejadian Kecelakaan Lalu Lintas Pada Pengendara Sepeda Motor Di Wilayah Polres Kabupaten Malang, Jurnal Ilmu Keperawatan Volume 1, No. 2.

Muladi, 2016, Kompleksitas Perkembangan Tindak Pidana dan

Kebijakan Kriminal. Cet. Pertama, Bandung: P.T.Alumni. Nurhasan, Juni 2017, Kebijakan

$$
\text { Restorative Justice Dalam }
$$

Penanganan Kasus Kecelakaan Lalu Lintas Di Wilayah Hukum

Polres Wonosobo, Jurnal Hukum Khaira Ummah Vol. 12. Sugiono, 2011, Metode Penelitian

Bandung: Alfabeta. Kuantitatif Kualitatif dan $R \& D$,

Utomo, Warsito Hadi. 2005, Hukum Kepolisian Di Indonesia. Prestasi

Pustaka, Jakarta. Utomo, Op.Cit.

Wawancara dengan Aiptu Triyono Anggota Unit Laka Lantas Polres

Pasuruan tanggal 3 April 2019. 